\title{
風によって誘発された低層建築物の室内圧のシミュレーション SIMULATION OF INTERNAL PRESSURES IN LOW-RISE BUILDINGS INDUCED BY WIND
}

\author{
上田宏*, 日比一喜**, 菊池浩利*** \\ Hiroshi UEDA, Kazuki HIBI and Hirotoshi KIKUCHI
}

\begin{abstract}
The external pressure on buildings causes variations in the pressures inside the buildings. This paper describes a simulation of internal pressure fluctuations that the wind induces in nominally sealed but actually leaky low-rise buildings. The internal pressure was measured by wind-tunnel experiments with models of low-rise buildings having leaky apertures. A simulation model was constructed to idealize, as a laminar flow in a circular pipe, the leakage flow in an aperture induced by the difference between the external and internal pressures. The external pressure fluctuations obtained from the experiments were fed to the model to simulate the internal pressure fluctuations induced in nominally sealed but actually leaky low-rise buildings. This simulation shows that the simulated fluctuations of internal pressure serve as a good representation of the results of the experiments.
\end{abstract}

Keywords : Low-rise building, Internal pressure, External pressure, Internal pressure simulation 低層建築物、室内压、外部風圧、室内圧シミュレーション

1. はじめに

建築物の外装材や屋根骨組等の風荷重を評価する際には、室内に作 用する室内圧の性状を把握することが極めて重要である。建築物の出 入口の扉や葖枠の周囲には、僅かな隙間が存在する。また、屋根や外壁 には、室内の空気を換気するためのモニタや換気口等が存在する。こ のような隙間や小さな開口部に、外部風圧が作用すると、そこには室 内圧との差圧が生じ、空気が室内へ流入または屋外へ流出するような 流れが発生する。そして、この流れのために、室内の空気密度の増減 が起り、室内圧の変化が誘発される。このため隙間や小さな開口を有 する建築物の室内圧の性状は、外部風圧の作用で隙間や開口部に生じ る空気の流れの状況に大きく影響される。そして、この流れの状況は、 外部風圧だけでなく、隙間や開口部の位置や形状 ${ }^{122)}$ 、室内の間仕切の

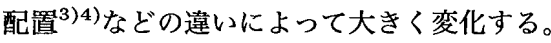

風によって誘発される建築物の室内圧に関する研究は、外部風圧 に比べると数が少ない。一般に、隙間や小さい開口部を有する建築 物の室内圧の時間的な平均値は、外部風圧と隙間や開口部を通過す る空気の流量の総和が零になる連続式を用いて評価される5)6)7)。し かし、外部風圧を定常として評価した場合の平均室内圧は、外部風 压を非定常として評価した平均室内圧と異なることが指摘されてい $ろ^{8)}$ 。立川 $(1969)^{9)}$ は、隙間を有する建築物の外部風圧の変動に対す る室内圧の変動は、理論的に考察することが可能であるとしている が、この事を検証するまでには至っていない。Vickery $(1986)^{10) 11) 、}$
Harris $(1990)^{8)}$ は、正圧場捻よび負圧場で空間平均した外部風圧を用い て、一様な隙間を有する建築物の室内压の変動を数值的にシミュレー トする方法を提案している。しかし、この方法は、隙間の位置や形状が 異なる場合や隙間が正圧場または負圧場に偏る場合、外部風圧場の空 間的な変化が大きい場合などには適用することが困難である。Oh, et al. $(2007)^{12)}$ は、多点同時測定した外部風圧を用いて、室内圧の変動を シミュレートする方法を提案している。この方法には、隙間の影響を 考慮するために、隙間流れに対して、レイノルズ数の影響を無視した 平衡状態に達した管路モデルを用いている。

強風時に葖ガラス等が破損した場合には卓越した開口が生じる ${ }^{13)}$ 。 この破損した卓越開口に、外部風圧が作用した場合には、室内圧の急 激な変化が生じる ${ }^{14) ~} 18$ )。風上面に卓越した開口を有する建築物の室 内圧の挙動および強風時に風上側の空ガラスが飛散物等で破壊されて 卓越した開口が発生した時の室内圧の過渡的な変化は、開口を出入り する空気塊の運動をへルムホルツ共鳴理論を適用してモデル化したへ

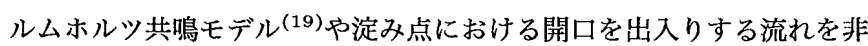
圧縮性の非定常型ベルヌーイ式を適用してモデル化したベルヌーイモ デル(20)、開口を通過する流れを非定常なオリフィス流れとしてモデル 化した非定常オリフィスモデル10)、開口と空気塊の運動との摩摖損失 を考慮したモデル12)21)などを用いて数值的にシミュレートすることが 可能である。しかし、先にも述べたように、強風や飛散物等で空がう スや出入り口の扉が破損した状況を除いて、一般の建築物が卓越した
* 千葉工業大学工学部建築都市環境学科 教授. 工博

** 清水建設(株技術研究所 リサーチフェロー・贡博 *** 清水建設(侏)技術研究所 主任研究員.工博
Prof., Dept. of Architecture and Civil Engineering, Faculty of Engineering, Chiba Institute of Technology, Dr. Eng.

Research Fellow, Institute of Technology, Shimizu Corporation, Dr. Eng.

Senior Research Engineer, Institute of Technology, Shimizu Corporation, Dr. Eng. 
開口を持つことは極めて稀である。

本研究では、上記の点を踏まえて、卓越開口を持たない、隙間のみ を有する建築物の室内圧の変動を、外部風圧模型による風洞実験で多 点同時測定される外部風压を用いて予測する方法を見い出すことを目 的とする。本論では、低層建築物の空枠や開閉扉の周囲の隙間を通過 する流れを円管路流に於ける助走区間流れで、また、小さい換気口等 の開口を通過する流れをオリフィス流れでそれぞれモデル化し、この 隙間に作用する外部風圧によって誘発される室内压の変動を数值的に シミュレーションする方法の妥当性を風洞実験による結果を踏まえて 検証する。

\section{2. 建築物の隙間率}

建築物の表面に存在する室内空間と外部空間とを結ぶ隙間は、風に よって誘発される室内圧の性状に大きな影響を及ぼすことが風洞実験 等で報告されている22)23)。よって、ここでは、先ずはじめに、強風時 の建築物の室内圧性状を把握する際に問題となる、建築物の隙間の状 況、特に隙間率について考察する。

建築物の室内圧を送風機等で減圧または加圧する試験を行った際に、 建築物の阥間から空気が流入または流出する時の単位時間当たりの空 気量 $Q$ と減圧または加圧時の室内外の圧力差 $\Delta P$ との関係は、経験 的に次式で表されることが知られている ${ }^{24)}$ 。

$$
Q=C A(|\Delta P|)^{n}
$$

ここに、 $A$ : 建築物の表面積 $\left(\mathrm{m}^{2}\right) 、 C:$ 流量係数 $\left(\mathrm{m}^{3} / \mathrm{s} \cdot \mathrm{m}^{2}(\mathrm{~Pa})^{\mathrm{n}}\right)$ 、 $|\Delta P|$ : 室内と屋外との圧力差の絶対值 $(\mathrm{Pa}) 、 n$ ：流れ指数である。

また、隇圧または加圧時に建築物の陌間 $j(=1,2, \cdots, N)$ から空気 が流入または流出する流れを、入口で急縮小し、出口で急挔大するオ リフィス流れとしてモデル化すると、全ての隙間から空気が流入する 場合や流出する場合の単位時間当たりの空気量 $Q$ は、

$$
Q=\sum_{j=1}^{N} a_{j} \sqrt{\frac{2|\Delta P|}{\rho C_{L}}}
$$

で表される。ここに、 $a_{j}$ : 弥間 $j$ の面積 $\left(\mathrm{m}^{2}\right) 、 C_{L}$ : 全ての隙間の圧力 損失係数 $(=1 / \sqrt{\kappa} 、 \kappa:$ オフィス流量係数 $) 、 N$ : 隙間の数である。 よって、この減圧または加压試験を実施した建築物の隙間率 $\mu$ (全 隙間面積を建築物の表面積で除した值）は、(1) 式および (2) 式におけ る、隙間を通過する空気の密度 $\rho$ を $1.2\left(\mathrm{~kg} / \mathrm{m}^{3}\right)$ 、全隙間の圧力損失 係数を $C_{L}=2.5$ とした場合に次式で表される。

$$
\mu=1.2 C(|\Delta P|)^{0.15}
$$

ただし、ここでの流れ指数 $n$ は、Tamura and Shaw $(1976)^{24)}$ 、Shaw and Jones $(1979)^{25)}$ 、Shaw $(1981)^{26)}$ らが実測結果に基づいて提案し ている値 $n=0.65$ を用いた。

(3) 式に於ける流量係数の実測結果について見てみると、1970 年〜 1974 年にカナダのオタワの 8 棟の気密性の高い建築物に類する高層ビル 24)の実測では、 $C \approx 1.1 \times 10^{-4} \sim 3.3 \times 10^{-4}$ で平均值が $2.1 \times 10^{-4}$ 、 1975 年にカナダの 11 棟の中程度の気密性の建築物に類する小学校の校舎 25)の実測では、 $C \approx 3.0 \times 10^{-4} \sim 7.0 \times 10^{-4}$ で平均值が $5.0 \times 10^{-4}$ 、 1978 年〜 1979 年に 10 棟の低気密建築物に類するスーパーマーケット

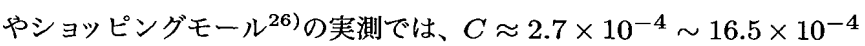
で平均値が $9.6 \times 10^{-4}$ が得られている。ただし、これらの単位は $\left(\mathrm{m}^{3} / \mathrm{s} \cdot \mathrm{m}^{2}(\mathrm{~Pa})^{0.65}\right)$ である。この実測值は、室内換気の評価を主な目 的としているため、圧力差が $100 \mathrm{~Pa}$ 以下の場合に限られた結果である。 一般の低層建築物の外装材用風荷重を $1500 \mathrm{~N} / \mathrm{m}^{2} \sim 2500 \mathrm{~N} / \mathrm{m}^{2}$ 程度 と考えると、ここでの圧力差としては、2000Pa 程度がほぼ妥当である が、この程度の圧力差に於ける流量係数についての情報は極めて少ない。 このため上記の流量係数を用いて、(3) 式を外挿して $2000 \mathrm{~Pa}$ の圧力差 に於ける上記の実測された気密性の異なる建築物のそれぞれの隙間率を 計算してみると、低い気密性の建築物の隙間率は $\mu \approx 0.0036 \pm .0026$ 、 中程度の気密性の建築物の隙間率は $\mu \approx 0.0018 \pm .0008$ 、高気密の建 築物の隙間率は $\mu \approx 0.0008 \pm .0004$ になる。Vickery $(1986)^{10)}$ によ れば、Davenport and Surry が提案している低気密建築物の隙間率は $0.0028 \pm .001 \dot{9}$ 、中程度の気密建築物の隙間率は $0.0015 \pm .0006$ 、高 気密建築物の隙間率は $0.0006 \pm .0003$ である。これらの隙間率は、上 記の流量係数を用いて、圧力差を $500 \mathrm{~Pa}$ として (3) 式より計算した值 にほぼ対応している。

よって、外装材や屋根骨組等の風荷重を評価する際の低層建築物の 隙間率は、低気密建築物を $0.36 \%$ 前後、中気密建築物を $0.18 \%$ 前後、 高気密建築物を $0.08 \%$ 前後と考えて差支えないと思われる。

\section{3．隙間を通過する流れのモデル化}

建築物の室内圧の性状または作用は、建築物の表面に於ける隙間に 作用する外部風圧とその時の室内压との差圧によって室内に流入また は屋外へ流出する空気の流量の状況に大きく影響される。このことは 隙間を通過する流れのモデル化が室内圧の変動をシミュレーションす るために必要不可欠であることを意味する。しかし、建築物の表面に 存在する隙間の形態は複雑で、その詳細を把握することは極めて困難 である。このため、ここでは、建築物の表面に於ける隙間または小さ い開口部の形態を大きく2つに分けて考える。その1つは、丞や悹枠 の周囲に存在するような、入口が狭く奧行きの長い隙間である。もう 1つは、小さい換気口のような、入口の寸法に比べて奥行きが短い隙 間である。隙間を通過する流れのモデル化に先立って、隙間を通過す る非定常な流れに含まれる慣性項の影響は、圧力損失項に比べて遥か

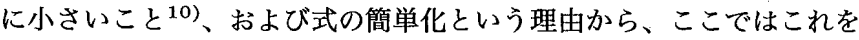
考慮しないことにする。

3. 1 助走区間流れによるモデル化

扉や空枠の周囲に見られるような、入口が狭く奥行きの長い隙間は、 円管路の入口付近の流れである助走区間流れでモデル化する。外部風 圧 $P_{e}$ と室内圧 $P_{i}$ の関係を $P_{e}>P_{i}$ とした時の助走区間流の圧力降 下と管壁摩摖との関係は次式で表される。

$$
P_{e}-P_{i}=\left(\lambda \frac{l_{0}}{d}+K_{0}\right) \frac{\rho \cdot u_{m}^{2}}{2}
$$

ここに、 $l_{0}$ ：助走区間長さで、隙間の場合は奥行き寸法 $(\mathrm{m}) 、 d:$ 管の 直径で、陌間の場合は高さ寸法 $(\mathrm{m}) 、 \lambda$ : ダルシーの管摩擦係数、 $K_{0}$ ： 付加的圧力降下係数、 $u_{m}$ ：管内の断面平均流速で、隙間の場合は隙間 の断面平均流速 $(\mathrm{m} / \mathrm{s}) 、 P_{e}$ : 外部風圧 $(\mathrm{Pa}) 、 P_{i}$ : 室内压 $(\mathrm{Pa}) 、 \rho$ : 空 気密度 $\left(\mathrm{kg} / \mathrm{m}^{3}\right)$ である。

一般に建築物の陌間を通過する流れは、レイノルズ数 $R_{e}\left(=u_{m} \cdot d / \nu\right.$ 、 $\nu$ : 動粘性係数) が $R_{e} \leq 10^{3}$ の非定常な層流と考えられている ${ }^{12) 27) 。 ~}$ Schiller ${ }^{28)}$ は、助走区間流れに於ける助走距離長さ $l_{0}$ を $l_{0}=0.029$. $R e \cdot d$ としている。例えば、隙間 $j$ を通過する流れのレイノルズ数が 
$R_{e j}=500$ で、隙間の直径または高さが $d_{j}=0.5 \mathrm{~mm}$ である時の助走 区間長さは $l_{0 j}=7.25 \mathrm{~mm}$ になる。ここで、付加的圧力降下係数 $K_{0}$ を $K_{0}=1.16^{28)}$ 、隙間 $j$ のダルシーの管摩擦俰数 $\lambda_{j}$ を $\lambda_{j}=64 / R_{e j}$ で与えると、隙間 $j$ を通って室内に流入する流れの断面平均流速 $u_{m j}$ は、

ただし、

$$
u_{m j}=k_{p j} \cdot \sqrt{\frac{2\left(P_{e j}-P_{i}\right)}{\rho}}
$$

$$
k_{p j}=\frac{1}{\sqrt{\frac{64}{R_{e j}}} \frac{l_{0 j}}{d_{j}}+K_{0}}
$$

ここに、 $P_{e j}$ : 弥間 $j$ に作用する外部風圧、 $k_{p j}$ : 助走区間流れの流量 係数で、これは隙間の入口寸法と奥行き寸法の比 $\left(=l_{0 j} / d_{j}\right)$ および レイノルズ数 $R_{e j}$ の関数になる。(5) 式より単位時間に隙間 $j$ を通っ て室内に流入する空気量 $Q_{j}$ は、

$$
Q_{j}=k_{p j} \cdot a_{j}\left(\frac{2}{\rho}\right)^{0.5} \sqrt{\left(P_{e j}-P_{i}\right)}
$$

で与えられる。ここに、 $a_{j}$ : 隙間 $j$ の面積 $\left(m^{2}\right)$ である。(7) 式における外 部風圧 $P_{e j}$ 扩よび室内圧 $P_{i}$ を建築物の軒高の速度压 $q_{H}\left(=0.5 \rho U_{r e f}^{2}\right)$ で除して、外部風圧係数 $C_{e j}$ および室内压係数 $C_{i}$ にして、流出また は流入する空気量 $Q_{j}$ を表現できるように (7) 式を書き改めると、

$$
Q_{j}=k_{p j} \cdot a_{j} \cdot U_{r e f}\left(C_{e j}-C_{i}\right)\left(\left|C_{e j}-C_{i}\right|\right)^{-0.5}
$$

になる。ここに、 $U_{r e f}$ : 軒高さ相当の平均風速 $(\mathrm{m} / \mathrm{s})$ である。ちなみ に、(8) 式における $C_{e j}-C_{i}$ の項が正（+）の場合が流入する空気量、 負 (一) の場合が流出する架気量を表す。

\section{2 円管オリフィス流れによるモデル化}

小型の換気扇の換気口のような、入口の寸法に比べて奥行きの短い 隙間は、円管オリフィス流れとしてモデル化する。この場合の隙間 $j$ を流入または流出する空気量 $Q_{j}$ は、外部風圧係数 $C_{e j}$ および室内压 係数 $C_{i}$ を用いて Vickery and Karakatsanis $(1987)^{29)}$ の式で表すこ とが出来る。

$$
Q_{j}=C_{o j} \cdot a_{j} \cdot U_{r e f}\left(C_{e j}-C_{i}\right)\left(\left|C_{e j}-C_{i}\right|\right)^{-0.5}
$$

ここに、 $C_{o j}$ ：弥間 $j$ のオリフィス流量係数である。円管オリフィス の流量係数は、主に開口比 $\left(=\left(a_{1} / a_{2}\right)^{2} 、 a_{1}\right.$ : 管の断面積、 $a_{2}$ :オリ フィス孔の断面積) の関数で、JIS 管オリフィスの流量係数 ${ }^{30}$ は 0.598 〜 0.804 の範囲としている。卓越開口を有する建築物の室内圧の変動 をシミュレートする際に、Liu and Rhee $(1986)^{31)}$ は、オリフィス流量 係数として 0.88 を、Sharma and Richards $(2003)^{32)}$ は 0.6 を用いて いる。ちなみに、(9) 式は、(8) 式の助走区間流れの流量係数 $k_{p j}$ を才 リフィス流れの流量係数 $C_{o j}$ に置き換えた式になっている。

\section{4. 室内圧の変動}

可逆断熱的に変化する空気の圧力 $P$ と密度 $\rho$ との関係は次式で表さ れる

$$
\frac{P}{\rho^{\gamma}}=\text { constant }
$$

ここに、 $\gamma:$ 定圧定積比熱比である。

ここでは、建築物の室内を間仕切の無い 1 つの空間と考えて、この 空間の容積を $V_{0}$ 、压力を $P$ 、空気密度を $\rho_{i}$ とする。ただし、圧力 $P$ は $P=P_{i}+P_{0}$ で、ここでの $P_{i}$ は室内压、 $P_{0}$ は静压である。
建築物の表面に於ける $N$ 箇所の隙間から微少時間に流入または流出 する空気量による室内の空気密度の变化は、

$$
\frac{d \rho_{i}}{d t}=\frac{\rho_{i}}{V_{0}} \cdot \sum_{j=1}^{N} Q_{j}
$$

(10) 式と (11) 式から窒内压の変動 $\left(=d P_{i} / d t\right)$ は、 $P=P_{0} 、 d P=d P_{i}$ として、次式のように表される。

$$
\frac{d P_{i}}{d t}=\frac{\gamma P_{0}}{V_{0}} \cdot \sum_{j=1}^{N} Q_{j}
$$

(12) 式を軒高風速 $U_{r e f}$ と外気の空気密度 $\rho_{e}$ 、(ただし、 $\left.\rho_{e}=\rho_{i}\right)$ で 室内圧係数 $C_{i}$ の式に書き改めると、

$$
\frac{d C_{i}}{d t}=\frac{2 \gamma P_{0}}{\rho_{e} V_{0} U_{r e f}^{2}} \cdot \sum_{j=1}^{N} Q_{j}
$$

になる。建築物の全ての隙間の形態が入口が狭く奥行きの長い陌間で ある場合の室内圧の変動は、(8) 式を(13) 式に代入した次式を数值的 に計算することで得られる。

$$
\left.\frac{d C_{i}}{d t}=\frac{2 \gamma P_{0}}{\rho_{e} V_{0} U_{r e f}} \cdot \sum_{j=1}^{N} k_{p j} \cdot a_{j}\left(C_{e j}-C_{i}\right)\left(\mid C_{e j}-C_{i}\right\}\right)^{-0.5}
$$

また、隙間の形態が全て入口の寸法に比べて奥行きが短い場合の室内 圧の変動は、(9) 式を(13) 式に代入した次式により得られる。

$$
\frac{d C_{i}}{d t}=\frac{2 \gamma P_{0}}{\rho_{e} V_{0} U_{r e f}} \cdot \sum_{j=1}^{N} C_{o j} \cdot a_{j}\left(C_{e j}-C_{i}\right)\left(\left|C_{e j}-C_{i}\right|\right)^{-0.5}
$$

さらに、上記の両方の隙間の形態が混在する場合の室内圧の変動は、隙 間に応じて (8) 式または (9) 式を (13) 式に代入し、多点同時測定され た外部風圧を用いて数值的に計算して得ることが出来る。

上述では、建築物の外壁や屋根等が剛であることを前提にして論を 進めてきが、本来、建築物の表面は風力によって変形する。特に、空気 膜構造物の場合は屋根等の変形が顥著である。このような変形は、室内 容積を変化させて室内压の変動にも影響を及ぼす。Vickery $(1986)^{10)}$ は、建築物の表面の変形に伴う室内圧への影響を考慮するために、次 式 ${ }^{33)}$ にるる有効容積 $V e$ を導入した。

$$
V_{e}=V_{0}\left(1+\frac{R_{a}}{R_{b}}\right)
$$

ここに、 $R_{b}$ は室内圧が $\Delta p_{i}$ だけ変化した時に表面が変形して、建築 物の容積 $V_{0}$ が $d v_{b}$ だけ変化した場合の単位室内圧当たりの容積変 化率の逆数 $\left(1 / R_{b}=d v_{b} / V_{0} \Delta p_{i}\right)$ で、 $R_{a}$ は建築物の表面を剛と考 えた場合、室内圧が $\Delta p_{i}$ だけ変化した場合に室内の空気密度 $\rho_{i}$ が $d \rho_{i}$ だけ変化した時の単位室内圧当たりの空気密度の変化率の逆数 $\left(1 / R_{a}=d \rho_{i} / \rho_{i} \Delta p_{i}\right)$ である。Vickery $(1986)^{10)}$ は、比較的剛な表面 の建筑物は $R_{a} / R_{b}=0.2$ 、柔らかい表面の建築物は $R_{a} / R_{b}=5$ とし ている。

建築物の表面の変形を考慮した室内圧の変動は、(14) 式または (15) 式に於ける建築物の容積 $V_{0}$ を(16) 式の有效容積 $V_{e}$ に䈯き換えるこ とで対応が可能である。

\section{5．隙間が外部風圧場に及ぼす影響}

密閉された建築物の表面に作用する外部風圧を用いて、隙間を有す る建築物の室内圧を計算する際には、隙間を出入りする空気の流れに 
よって外部風圧場が影響されることが考えられる。これによって計算 結果に誤差が生じることが懸念される。Kandola $(1978)^{34)}$ は、立方体 模型を用いた風洞実験で、各々の隙間の隙間率が $0.1 \%$ 以下で、かつ、 その壁面で累積した隙間率（全隙間面積をそれらの隙間を含む壁面積 で除した值）が $3 \%$ 以下であれば、壁面の隙間が外部風圧場に及ぼす影 響は小さいとしている。Georgiou and Vickery $(1979)^{35)}$ は、風向に正 対する平板の抗力（風上面と風下面の圧力差）に対する隙間平板の抗 力の変化割合を次式で与えている。

$$
\Delta P_{\mu} / \Delta P_{0}=(1-\mu)(1+0.3 \mu)
$$

ここに、 $\Delta P_{\mu}$ : 隙間率 $\mu$ の抗力、 $\Delta P_{0}$ : 平板の抗力である。

また、上田ら $(1999)^{36)}$ は、風向に正対する網状平板と充実平板の 抗力の変化割合を次式で与えている。

$$
\Delta P_{\mu} / \Delta P_{0}=1.4 \log (K+0.6-\sqrt{1.2 K+0.36})-1.4 \log K+1.0
$$

ここに、 $K=1.2(1-\mu) / \mu^{2}$ である。

Richards and Robinson(1999) ${ }^{37)}$ は、風向に正対するネットフェン スと充実フェンスの抗力の変化割合を次式で与えている。

$$
\Delta P_{\mu} / \Delta P_{0}=\left(1-\mu_{e}\right)
$$

ここに、 $\mu_{e}$ : フェンスの有効隙間率 ( $=0.75 \mu 、 \mu$ : フェンスの隙間率) である。

(17) 式、(18) 式、(19) 式を図1に示す。これより、風上面の外部風 圧場に対する隙間の影響は、隙間率が $1 \%$ 以下であれば、1\%末満に押 さえられることが分かる。Hold, et al. $(1983)^{38)}$ は、切妻型低層建築 物（Aylesbury）の縮尺模型を用いた風洞実験によって、表面における 隙間が外部風圧場の評価に及ぼす影響について考察し、外部風圧場に対 する顕著な影響は、表面に一様に分布する全隙間面積が表面積の $3 \%$ 以 下で、かつ、各々の隙間面積が表面積（隙間を含む表面）の $0.75 \%$ 以 下であれば小さいこと、風向が掠めるような壁面における陌間の隙間 率が $0.75 \%$ を超えると外部風王場に乱れが生じることを報告している。 Vickery and Karakatsanis $(1987)^{29)}$ は、外部風王によって誘発される 低層建築物の内部の換気流れを予測する場合の壁面近傍の外部流れと 隙間との関係を考察し、壁面に沿うような流れ場では、隙間の面積が 小さければ、壁面に沿う流れを室内一吸い込む流量が少なくなるため に、流れの形態はそれほど大きく変化しないが、隙間面積が大きくな ると室内へ吸い込む流量が多くなるため、壁面近傍の流れが大きく歪

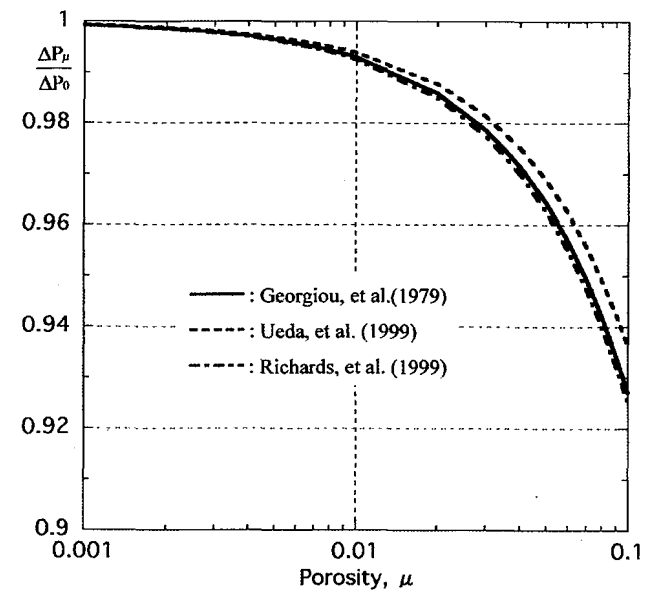

図 1 風向に正対する面の外部風圧場に対する隙間率の影響
められ、外部風圧場も大きく変化する、そして、この傾向は壁面近傍 の速度が速い場合により強まることなどを見い出している。前述のよ うに、気密性の低い建築物の間隙率は $0.36 \%$ 程度、中程度の気密の建 築物の間隙率は $0.18 \%$ 程度、高気密性の建築物の隙間率は $0.08 \%$ 程度 であることから、この程度の隙間率の壁面に作用する外部風圧場に対 する隙間の影響は、上記の結果からして、極めて小さいと判断出来る。

ここでは、上記の結果を踏まえて、陌間率が $0.06 \% \sim 0.25 \%$ 程度の 隙間を有する低層建築物模型の室内圧の変動を、同じ形状の閉鎖型模型 による風洞実験で多点同時測定した外部風圧と (14) 式を用いてシミュ レーションすることを試みる。

\section{6. 風洞実験}

室内圧の変動をシミュレーションする際に用いる外部風圧の時系列 データおよびシミュレーションの結果を検証するための室内圧の時系 列デー夕を得るために風洞実験を実施した。ここでは、この風洞実験 の方法等について述べる。

\section{1 風洞気流}

実験は回流式の閉鎖型境界層風洞 $\left({ }^{W} 3.5 \mathrm{~m} \times{ }^{H} 2.5 \mathrm{~m} \times{ }^{\mathrm{L}} 20 \mathrm{~m}\right)$ で行つ た。風洞気流は，測定胴の入口に Irwin Type のスパイヤー抢よび充 実フェンスを配置し、そこから測定部のターンテーブルまでの測定胴 の床に大小 2 種類のラフネスブロックを密度が等しくなるように千鳥 に思考錯誤して配置した。このように作成した乱流境界層流は、図 2 に示すように、粗度長は $Z_{0}=0.042 \mathrm{~cm}$ で、風速の鉛直分布のべき指 数は $\alpha=0.17$ である。床から $4 \mathrm{~cm}$ の高さ（これは後に述べる模型の

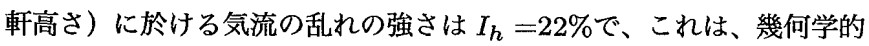
な縮尺率を $S=1 / 250$ とした場合、風荷重指針 ${ }^{39}$ )で推奨する粗度区分 II の乱れの強さ $I_{\mathrm{r}} z=23 \%$ にほぼ対応する。主流方向の乱れのスケー ルは約 $36 \mathrm{~cm}$ 、縮尺率を $1 / 250$ とした場合の実スケールは $L_{u}=90 \mathrm{~m}$ で、これも風荷重指針 $\left.{ }^{39}\right)$ の推奨值 $L_{z}=100 \mathrm{~m}$ に概ね対応する。また、 この高さでの乱れのパワースペクル密度分布は Kármán 型のスペクト ルによく対応している。これらの結果から、ここで作成した風洞気流 は、強風時の平坦地域に相当する縮尺率 $S=1 / 250$ の気流と看做すこ とが出来る。

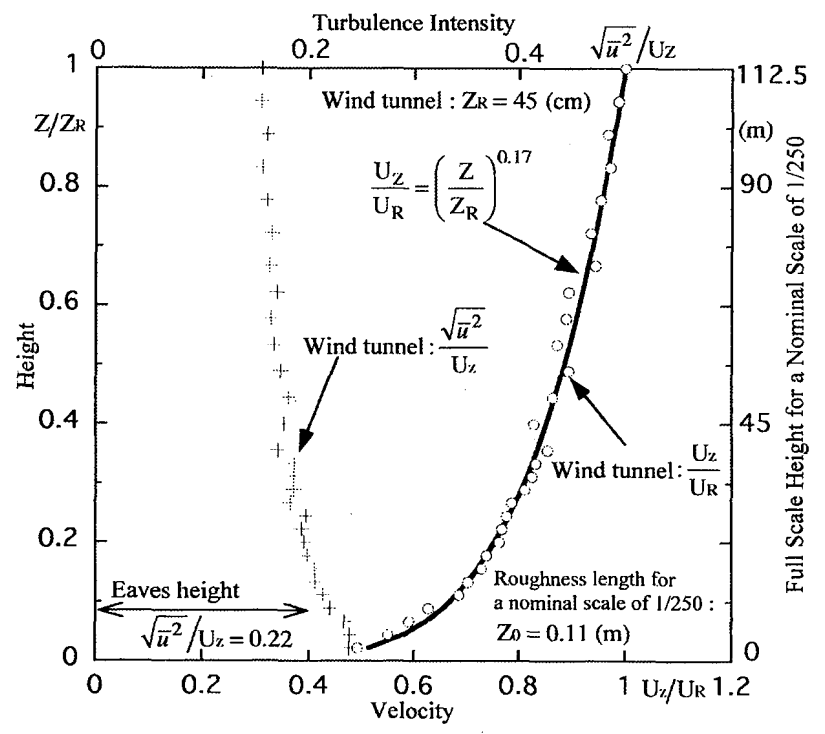

図2 風洞気流の特性 


\section{2 外部風圧測定}

外部風圧を測定するための模型は、幅が $16 \mathrm{~cm}$, 高さが $4 \mathrm{~cm}$ ， スパ ンが $10 \mathrm{~cm}$ のアクリル製の低層陸屋根模型である。外部風圧測定点は 屋根と壁面に計 144 点を設けた。外部風圧は測定孔に取り付けたアル ミニウム製のパイプ (内径 $0.8 \mathrm{~mm}$ 、長さ $8 \mathrm{~mm}$ ) からビニール製の導 圧管 (内径 $1 \mathrm{~mm}$ 、長さ $1 \mathrm{~m}$ ) で多点圧力計に導いて模型の上方に設置 したピト一管の静压との差圧として全点同時に測定した, 導压管の影 響は管の圧力伝達関数を求めて補正した，圧力計からの出力信号は、 $500 \mathrm{~Hz}$ のアナログローパスフィルターを通してから、サンプリング間

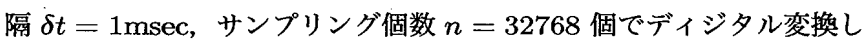
た後、遮断周波数が $100 \mathrm{~Hz}$ のディジタルローパスフィルター処理を行 い, 模型の軒高相当の速度圧で除して外部風圧係数の時系列データと して収録した。測定部のターンテーブルの中央に設置した模型の長辺 に対して気流が正対する方向を $\alpha=0^{\circ}$ として、反時計回りに $5^{\circ}$ 間隔 に $90^{\circ}$ までテーブルを回転させて模型に入射する気流の方向を変えて 外部風圧を測定した。

\section{3 室内圧測定}

外部風圧によって誘発される室内圧を測定するために、外部風圧模 型と同じ外形寸法で相似則を満たすための空気槽を取り付けた室内圧 模型を $5 \mathrm{~mm}$ 厚のアクリル板で製作した。空気槽の大きさは、建築物 の室内圧が隙間から流入または流出する空気によって可逆断熱変化す る際の状態方程式を実物と模型とが満足するように次式によって決定 した ${ }^{40)}$ 。

$$
\Psi_{v}=\frac{\left(\Psi_{l}\right)^{3}}{\left(\Psi_{u}\right)^{2}}
$$

ここに、 $\Psi_{v}$ : 容積スケール、 $\Psi_{l}$ : 幾何学スケール、 $\Psi_{u}$ : 風速スケールで ある。よって、内部容積 $V_{N}=9547 \mathrm{~m}^{3}$ の建築物を幾何学スケールが $\Psi_{l}=1 / 250$ 、室内圧測定時の軒高さ平均風速 $U_{r e f}$ は $10 \mathrm{~m} / \mathrm{s}$ 、実風速 は $U_{r e f}=35 \mathrm{~m} / \mathrm{s}$ とし, 軒高さ相当の風速スケールを $\Psi_{u}=1 / 3.5$ で 模型化した時の模型内部の容積は $V_{M}=7.5 \times 10^{-3} \mathrm{~m}^{3}$ になる。ここ で、模型内部の断面積を $1.35 \times 10^{-2} \mathrm{~m}^{2}$ とすると、模型内部の容積の 高さ、すなわち、空気槽の高さは $0.56 \mathrm{~m}$ になる。このようにして作成 した室内压模型をターンテーブルに設置した状況を図 3 に示す。室内 圧模型の壁面には、外部風圧測定孔の位置を考慮して図 4 に示すよう な位置に $0.5 \mathrm{~mm} \phi 、 0.8 \mathrm{~mm} \phi 、 1.0 \mathrm{~mm} \phi$ の円形の孔を隙間として設け た。各壁面に於ける孔の累積隙間率は表 1 に示す。前述の建築物の気密 性の考察から、0.5mm $\phi$ の円形孔の隙間を設置した室内圧模型は高気

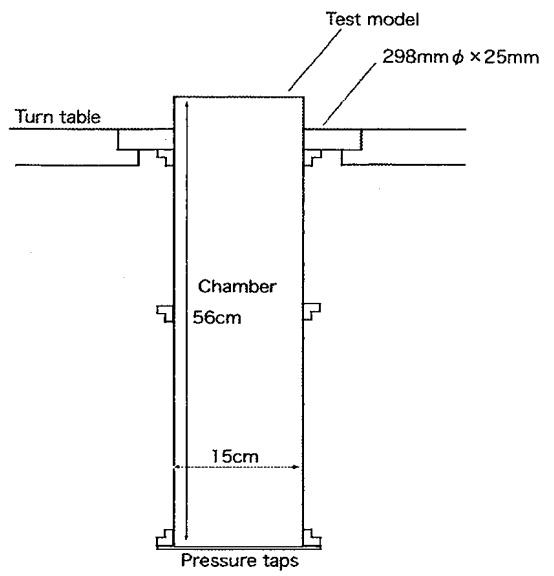

図 3 室内圧模型の設置状況

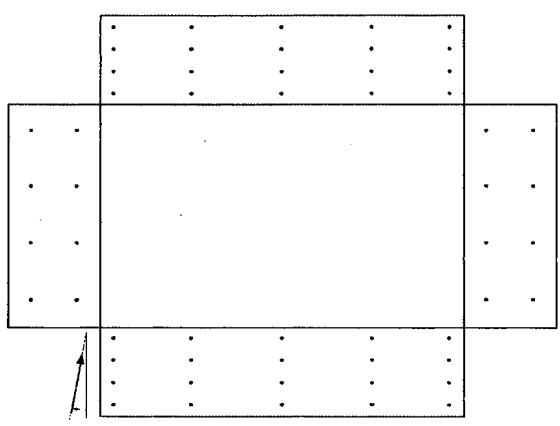

図4 室内圧模型に於ける円形孔の設置状況

表 1 壁面に設けた円形孔の累積隙間率

\begin{tabular}{c|c|c|c}
\hline 壁面寸法 $(\mathrm{mm})$ & $0.5(\mathrm{~mm} \phi)$ & $0.8(\mathrm{~mm} \phi)$ & $1.0(\mathrm{~mm} \phi)$ \\
\hline $160 \times 40$ & $0.061(\%)$ & $0.157(\%)$ & $0.245(\%)$ \\
$100 \times 40$ & $0.039(\%)$ & $0.100(\%)$ & $0.157(\%)$ \\
\hline
\end{tabular}

密な建築物、0.8mm $\phi$ の隙間を設置した模型の気密性はほぼ中程度の 気密建築物に、 $1.0 \mathrm{~mm} \phi$ の腺間を設置した模型の気密性はやや低気密 な建築物に相当する。模型の室内圧は、壁面全体および壁面の一部に隙 間を設けた 4 ケースについて、空気槽の底（図 3 ）の6 ケ所に取り付け た圧力測定孔から室内圧を外部風圧を測定する際に用いた導圧チュー ブを用いて圧力計に導いて測定した。圧力計からのアナログ出力は、外 部風圧と同じサンプリング条件で A-D 変換した後、軒高の速度圧で除 して室内圧係数として収録した。

\section{7. 室内圧のシミュレーションと実験結果との比較検討}

ここでは、外部風圧模型を用いて多点同時測定した外部風圧が室内 圧模型の円形孔に作用した際に誘発するであろう室内圧の変動を、入 口の寸法に比べて奥行き寸法の長い隙間に対応する (14) 式をルンゲ・ クッ夕法で数值的に解いて求める。そして、このシミュレーションの 結果と室内圧模型で測定した室内圧の変動を比較することによってシ ミュレーションの妥当性を検証する。

7. 1 シミュレーション

シミュレーションは、風向が建築物の桁行方向（長辺方向）の壁面に正 対する場合で、全壁面に隙間を設けた場合、風上面にのみ隙間を設けた場 合、風向に平行な両側面に隙間を設けた場合の 3 ケースについて行った。 建築物の容積は、表面を剛であると仮定し、 $V_{e}=V_{0}=9547 \mathrm{~m}^{3}$ とした。 軒高風速は $U_{r e f}=35 \mathrm{~m} / \mathrm{s}$ 、空気密度は $\rho_{e}=\rho_{i}=1.2 \mathrm{~kg} / \mathrm{m}^{3}$ 、定圧定 積比熱比は $\gamma=1.4$ 、静圧 $P_{0}=10^{5} \mathrm{~Pa}$ 、隙間の面積は $0.5 \mathrm{~mm} \phi$ の場 合が $a_{j}=1.23 \times 10^{-2} \mathrm{~m}^{2} 、 0.8 \mathrm{~mm} \phi$ の場合が $a_{j}=3.14 \times 10^{-2} \mathrm{~m}^{2}$ 、 $1.0 \mathrm{~mm} \phi$ の場合が $a_{j}=4.91 \times 10^{-2} \mathrm{~m}^{2}$ である。(6) 式より流量係数 を定める際の $l_{0 j} / d_{j}$ は、 $0.5 \mathrm{~mm} \phi$ の場合が $l_{0 j} / d_{j}=10 、 0.8 \mathrm{~mm} \phi$ の 場合が $l_{0 j} / d_{j}=6.25 、 1.0 \mathrm{~mm} \phi$ の場合が $l_{0 j} / d_{j}=5$ である。外部風 圧によって誘発される室内圧の変動は、隙間の位置や大きさ、さらに 隙間を通過する流れの流量係数に影響されるが、この隙間流れを助走 区間流れ之考えた場合の流量係数は、(6) 式から分かるように、レイノ ルズ数、弥間の形状係数、付加的圧力降下係数などに影響される。し たがって、シミュレーションと実験とを比較する場合の隙間の形状係 数 $l_{0 j} / d_{j}$ と付加的圧力降下係数 $K_{0}$ は、前述のように定められるが、 実験時のレイノルズ数を客観的に定めることは甚だ困難である。そこ で、ここでは、室内圧模型によって得られた室内圧変動のパワースペ クトル密度分布にシミュレーションの結果が近似する時のレイノルズ 
数を実験時の隙間を通過する流れのレイノルズ数とした。

\section{2 隙間を通過する流れのレイノルズ数}

上述の方法で求めた隙間の位置および大きさに対するレイノルズ数 は、表 2 に示すように、 $1 \mathrm{~mm} \phi \sim 0.5 \mathrm{~mm} \phi$ の円形孔の隙間が、全壁 面に配置された場合はほぼ $R_{e} \approx 200$ 、風上壁面にのみ配置された 場合は $R_{e} \approx 100 \sim 30$ 、風向に平行な両壁面に配置された場合は $R_{e} \approx 600 \sim 100$ である。これらは、前述した然枠の隙間を通過する 空気流量とレイノルズ数の関係を実験的に考察した結果 ${ }^{27)}$ から見い出 された $R_{e} \leq 10^{3}$ ともほぼ対応する。また、Oh, et al. ${ }^{12)}$ は、建築物 の隙間を通過する流れのレイノルズ数を 400 以下としているが、ここ ではこの值を概ね満足している。隙間の径が小さいとそこを通過する 流れは流れ難く、流量が減少するために流量係数が小さくなる傾向が 認められる。また、隙間の径が同じでも、隙間を有する壁面の配置の 違いで室内圧が異なるために、その隙間を通過する流れの流量特性が 変化する傾向が認められる。例えば、風上壁面にのみ陌間がある場合 には、同一壁面内で空気が流入する箇所と流出する箇所が混在し、室 内压と外部風圧が共に正圧であるために、両者の差压がそれ程大きく ならず、単位時間に隙間を流出または流入する空気の流量も少なく、そ のため全壁面に隙間がある場合や風向に平行な両側面に隙間がある場 合に比べて、隙間の径が同じであっても、流量係数は小さくなると考 えられる。

\section{3 室内圧係数}

表 2 に示すように、全壁面に隙間を設けた場合の模型実験の平均室 内圧係数は $\bar{C}_{i}=-0.23 \sim-0.15$ で隙間の径による差異はそれほど大き くない。また、風上側にの夕隙間を設けた模型の平均室内圧係数は、 $\bar{C}_{i}=0.29 \sim 0.28$ の正圧で、隙間の径の違いによる差異は極めて小さ い。風に平行な両側面に陌間を設けた模型で測定した平均室内圧係数 は、 $\bar{C}_{i}=-0.5 \sim-0.48$ で他のケースに比べて低く、この場合も隙間の 径の違いによる差異は小さい。模型実験とシミュレーションの平均室内 圧係数を見比べてみると、実験結果であることとシミュレーションの 結果であることを考慮すれば、両者はほぼ対応していると言える。変 動室内圧係数 $C_{i}^{\prime}$ について見てみると、全壁面に隙間を有する場合の 変動室内圧係数は、風上壁面にのみ隙間が有る場合や両側面に隙間が 有る場合に比べて、模型実験およびシミュレーション共に小さい。こ れにはそれぞれの壁面に作用する外部風圧の相関性が関係していると 考えられる。また、隙間孔が $0.5 \mathrm{~mm} \phi$ の変動室内圧係数は、他の隙間 孔の值に比べて 5 割程度小さく、後に示す図 5 または図 6 の波形にも この傾向が表れている。模型実験とシミュレーションの変動室内圧係 数に特に顕著な差異は認められない。

\section{表 2 平均および変動室内圧係数}

\begin{tabular}{|c|c|c|c|c|c|c|c|}
\hline \multirow{2}{*}{$\begin{array}{c}d \\
(\mathrm{~mm} \phi)\end{array}$} & \multirow{2}{*}{$R_{e}$} & \multirow{2}{*}{$k_{p}$} & \multicolumn{2}{|c|}{$\bar{C}_{i}$} & \multicolumn{2}{|c|}{$C_{i}^{\prime}$} & \multirow{2}{*}{$\begin{array}{l}\text { Locations } \\
\text { of Porosity }\end{array}$} \\
\hline & & & Sim & Exp & Sim & Exp & \\
\hline 1.0 & 200 & 0.60 & -0.21 & -0.23 & 0.08 & 0.08 & \\
\hline 0.8 & 200 & 0.56 & -0.20 & -0.20 & 0.08 & 0.08 & $\leftarrow$ \\
\hline 0.5 & 200 & 0.48 & -0.20 & -0.15 & 0.06 & 0.05 & \\
\hline 1.0 & 100 & 0.48 & 0.33 & 0.29 & 0.14 & 0.16 & \\
\hline 0.8 & 100 & 0.44 & 0.32 & 0.28 & 0.13 & 0.13 & 4 \\
\hline 0.5 & 30 & 0.21 & 0.31 & 0.28 & 0.06 & 0.09 & \\
\hline 1.0 & 600 & 0.77 & -0.48 & -0.48 & 0.13 & 0.12 & \\
\hline 0.8 & 300 & 0.63 & -0.46 & -0.49 & 0.12 & 0.11 & $\leftarrow$ \\
\hline 0.5 & 100 & 0.36 & -0.46 & -0.50 & 0.06 & 0.06 & \\
\hline
\end{tabular}

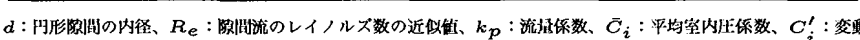

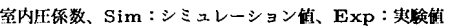

\section{4 室内圧の変動状況}

図 5 (a) 〜 (c) は、全壁面に隙間を設けた室内圧模型で測定した室 内压の波形である。これからも隙間が小さくなると室内圧の変動が小 さくなり、高い周波数の変動が低隇している様子が見て取れる。図 5 (d)～(f) は、この隙間の室内圧の変動をシミュレーションした波形で ある。シミュレーションの波形にも隙間の滅少で変動が抑制される状
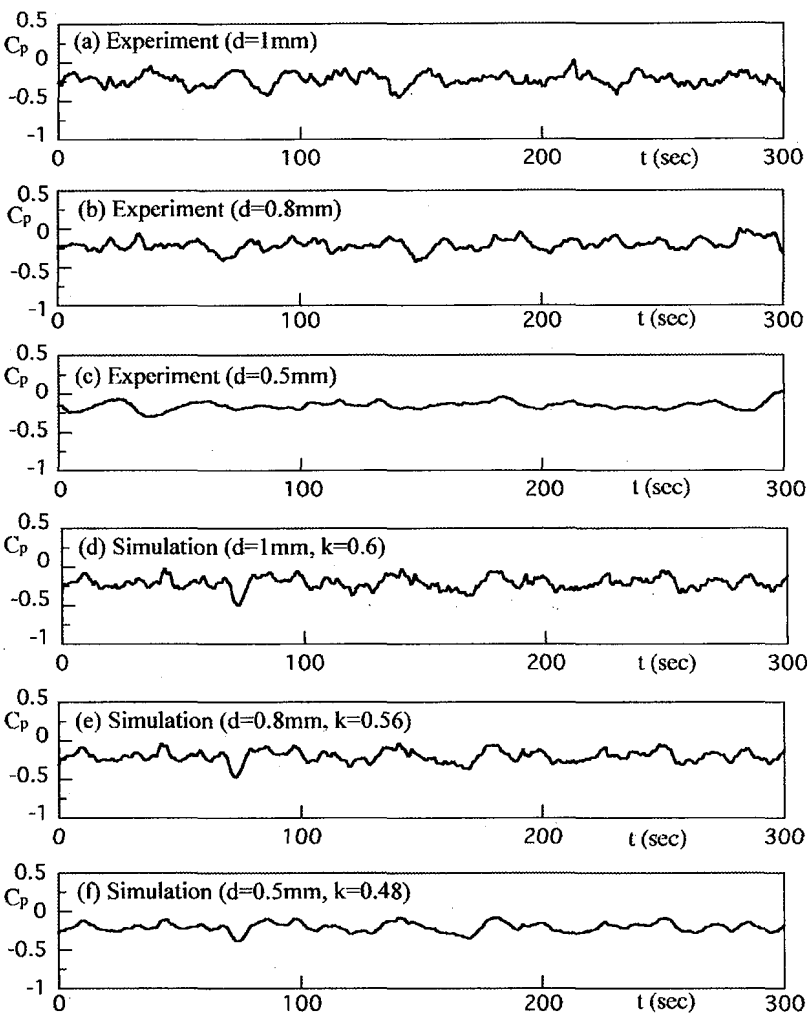

図 5 全ての壁面に隙間孔を有する場合の室内圧波形
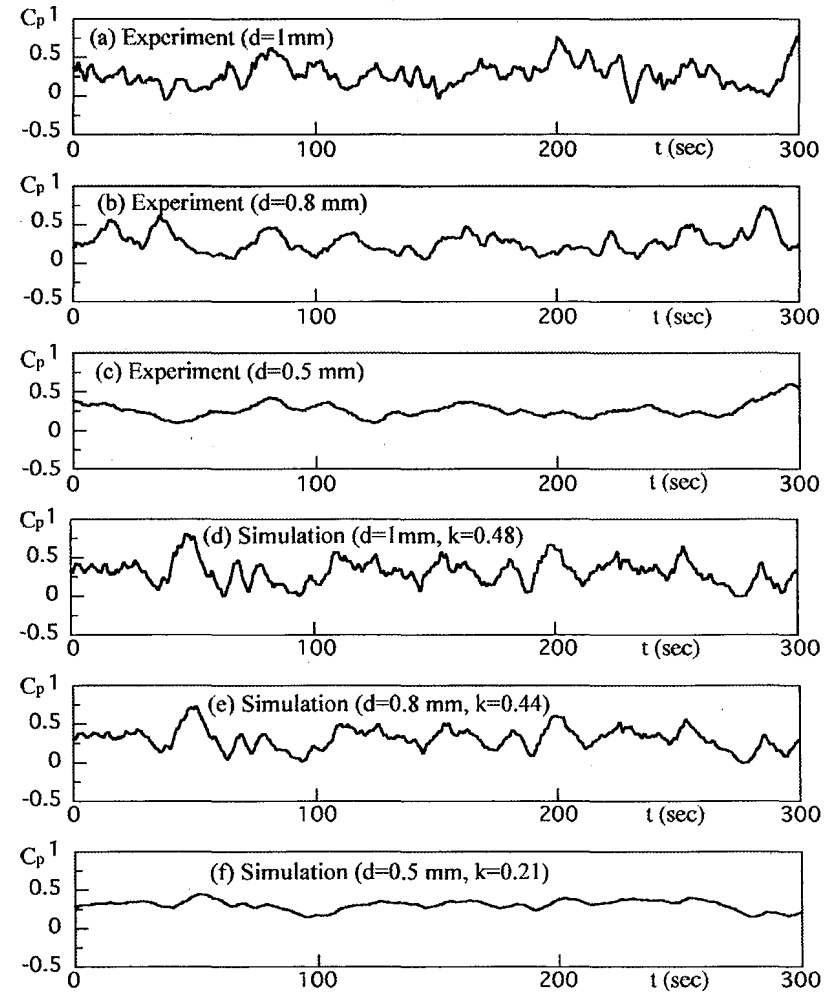

図 6 風上壁面に隙間孔を有する場合の室内圧波形 
況など、図 5 (a) 〜 (c) の模型害験の波形に類似した変動状況が認め られる。図6 (a)〜 (f) は、風上壁面にのみ腺間を設けた場合の模型 実験とそのシミュレーションの室内圧波形の比較である。この風上隙 間の室内圧変動は、風上壁面に作用する外部風圧の変動によってのみ 誘発されることから、図 5 (a) 〜 (c) に示す全隙間の室内圧の変動に 比べて、外部風圧との相関性が高くなるために大きな変動が生じると

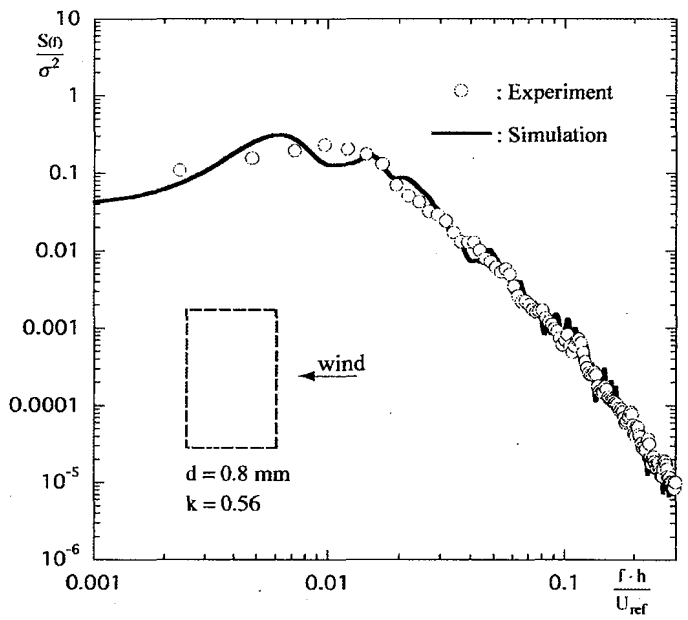

（a）全壁面に隙間を有する場合

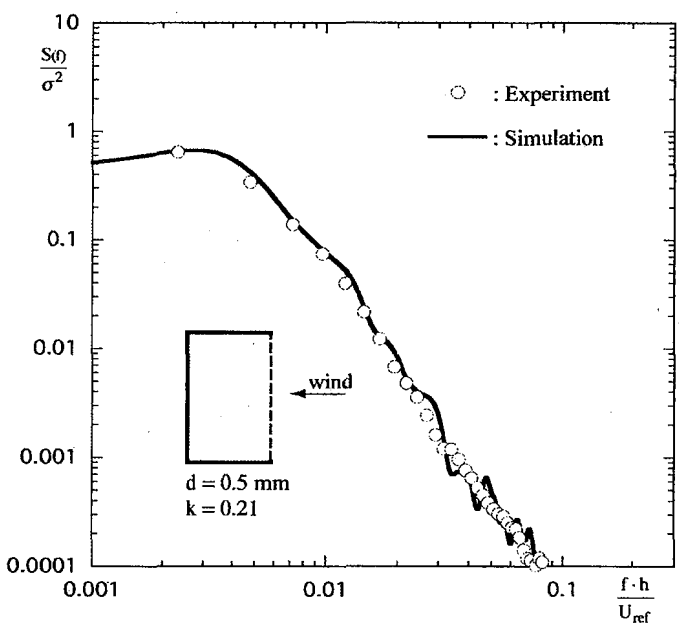

（b）風上壁面に陌間を有する場合

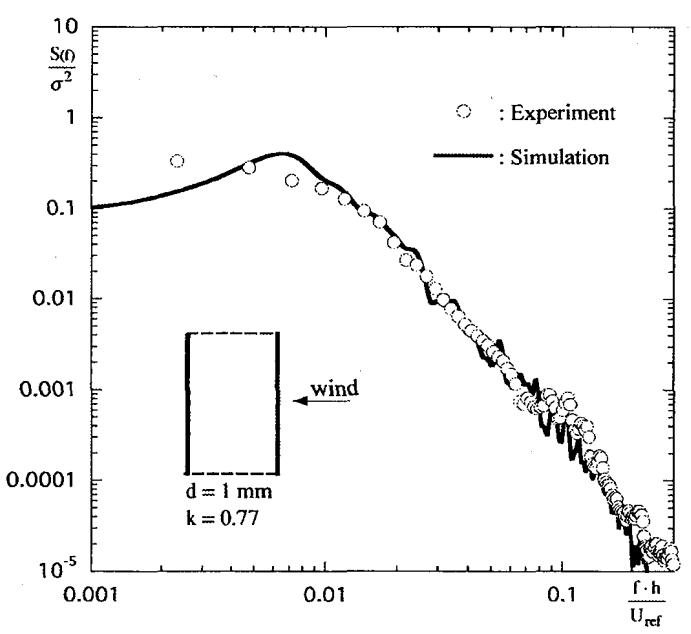

（c）両側壁面に隙間を有する場合

図 7 室内圧の規準化パワースペクトル密度分布
考えられる。また、この場合も模型実験とシミュレーションの波形に は、隙間の滅少で室内压の変動が狮制される様子が見られる。

\section{5 室内圧変動のパワースペクトル密度分布}

模型実験とシミュレーションの室内圧変動のパワースペクトル密度 分布は、図 7 に示すように、良く対応している。腺間を有する建築物 の室内圧の変動は、速度圧や外部風圧の変動に比べて高周波数域で隇

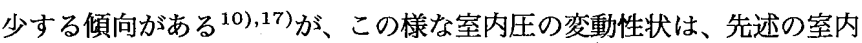
圧波形やパワースペクトル密度分布からも認められる。

\section{8. まとめ}

本論では、風によって誘発される隙間を有する低層建築物の室内圧の 変動を、風洞においてこの低層建築物の閉鎖型模型で多点同時測定し た外部風圧および隙間を通過する流れをモデル化した式を用いて、数 值的にシミュレーションする方法などについて検討した。その結果、外 装材や屋根骨組等の風荷重を評価する際の建築物の隙間率は $0.36 \%$ $0.08 \%$ 程度であること、模型に設けた隙間を出入りする気流による外 部風圧場への影響は、隙間率が $1 \%$ 以下であれば $1 \%$ 未満であること、 風洞において円形孔の隙間を有する低層陸屋根模型の外部風圧による 室内圧の変動は、同じ寸法の閉鎖型模型で多点同時測定した外部風圧 および隙間を通過する流れを管路流に於ける助走区間流れでモデル化 した式を用いて、数值的にシミュレーション出来ることなどの知見を 得た。本論で得られた知見が建築物の外装材や屋根骨組等の風荷重を 評価する際の室内圧の資料として役立つことが出来れば幸いである。

\section{参考文献}

1) Van Koten, H.: The Wind Pressures on Windows, Symposium on Full-scale Measurements on Wind Effects, London, Ontario 1974

2) Liu, H. : Building Code Requirements on Internal Pressure, Proceedings of the 3rd United States Wind Engineering Conference, February 26-March, pp.475-478 1978

3) Saathoff, P. J. and Liu, H. : Internal Pressure of Multi-Room Buildings, Journal of the Engineering Mechanics Division, ASCE, Vol.109, No.3, June, pp.908-919 1983

4) Liu, H. : Wind Tunnel Modeling of Building Internal Pressure, ASCE, Vol. 108, No. TE6, November, pp.691-696 1982

5) Newberry, C. W. and Eaton, K. J. : Internal Pressures, Wind Loading Handbook, pp.47-55 1974

6) Stathopoulos, T. and Kozutsky, R. : Wind-induced Internal Pressures in Buildings, Journal of Structural Engineering, Vol. 112, No.9, September, pp.2012-2026 1986

7）茅野紀子, 岡田恒：涌風設計における建築物の室内圧に関する研焭（その 1) 平均室内压係数, 日本風工学会誌, 第 56 号, pp.11-21 1993.7

8) Harris, R. I. : The Propagation of Internal Pressures in Buildings, Journal of Wind Engineering and Industrial Aerodynamics, 34, 169-184 (1997)

9）立川正夫：自然風中において構造物に作用する風圧力に関する実験的研究一 その 5 ・補足的考察と結語一, 日本建築学会論文報告集, 第 160 号, pp.17 $\sim 21.1969 .6$

10) Vickery, B. J. : Gust-factors for Internal-pressures in Low Rise Buildings, Journal of Wind Engineering and Industrial Aerody- 
namics, 23, 259-271 (1986)

11) Vickery, B. J. : Internal pressures and interactions with the building envelope, Journal of Wind Engineering and Industrial Aerodynamics, 53, 125-144 (1994)

12) Oh, J. H., Kopp, G.A. and Inculet, D.R. : The UWO Contribution to the NIST Aerodynamic Database for Wind Loads on Low Buildings: Part3. Internal Pressures, Journal of Wind Engineering and Industrial Aerodynamics, (2007), doi:10.1016/j.j weia.2007.01.007

13) Minor, J.E. : How to prepare glass buildings for hurricanes, Gass Digest, November,15, pp.60-64 1984

14）大熊武司、金谷昭男 : 強風時に空面破壊に伴なう内圧の変化とその性状につ いて、第 6 回風工学シンポジウム, pp.131-137 1980.11

15) Liu, H. and Saathoff, P.J.: Internal Pressure and Building Safety, Journal of the Structural Division, A.SCE, Vol.108, No.ST10, October, pp.2223-2233 1980

16) Stathopoulos, T. and Luchian, H.D. : Transient Wind -Induced Internal Pressures, Journal of Engineering Mechanics Division, ASCE, Vol.115, No.7, July, pp.1501-1514 1989

17）上田宏、桂順治、藤澤一善、藤井邦雄：強風中にお施低層建築物の室内圧に 関する研究、日本建築学会構造系論文報告集, 第 434 号, pp51-58 1992.4

18) Vickery, B.J. and Bloxham, C. : Internal pressure dynamics with a dominant opening, Journal of Wind Engineering and Industrial Aerodynamics, 41-44, pp.193-204 (1992)

19) Holmes, J. D. : Mean and Fluctuating Internal Pressures Induced by Wind, Proceedings of the Fifth International Conference on Wind Engineering, Colorado State University, pp. 553-565 July (1980)

20) Liu, H. and Saathoff, P. J. : Building Internal Pressure: Sudden Change : Journal of the Engineering Mechanics Division, ASCE, Vol. 107, No. EM2, pp.309-321, April 1981

21) Sharma, R. N. and Richards, P. J. : Computational Modelling of the Transient Response of Building Internal Pressure to a Sudden Opening, Journal of Wind Engineering and Industrial Aerodynamics, 72, pp.149-161 (1997)

22) Stathopoulos, T., Surry, D. and Davenport, A. G. : Internal Pressure Characteristics of Low-rise Buildings due to Wind Action, Proceedings of the Fifth International Conference on Wind Engineering, Colorado State University, pp.451-463, July (1980)

23) Woods, A.R. and Blackmore, P.A. : The effect of dominant openings and porosity on internal pressures, Journal of Wind Engineering and Industrial Aerodynamics, 57, pp.167-177 1995

24) Tamura, G.T. and Shaw, C.Y.:Study on External Wall Air Tightness and Air Infiltration of Tall Buildings, ASHRAE Transactions, Vol.82, Part1, pp.122-133 1976
25) Shaw, C.Y. and Jones, L. : Air Tightness and Air Infiltration of School Buildings, ASHRAE Transactions, Vol.85, Part1, pp.85-95 1979

26) Shaw, C.Y. : Air Tightness: Supermarkets and Shopping Malls, ASHRAE JOURNAL, March, pp.44-46 1981

27) Building Research Establishment Digest : Principles of Natural Ventilation, Digest 210, February pp.1-8 1978

28) Schiller, I. : Untersuchung über laminare und turbulente Strömung, Z. ang. Math. Mech. 2, S.96 1922

29) Vickery, B.J. and Karakatsanis, C. : External Wind Pressure Distributions and Induced Internal Ventilation Flow in Low-raise Industrial and Domestic Structures, ASHRAE Transactions, Vol.93, Part1, pp.2198-2213 1987

30) JIS Z 8762-1969,JIS 管オリフィスの流量係数

31) Liu, H. and Rhee, K.H.:Helmholtz Oscillation in Building Models, Journal of Wind Engineering and Industrial Aerodynamics, 24, pp.95-115 (1986)

32) Sharma, R. N. and Richards, P. J. : The influence of Helmholtz resonance on internal pressures in a low-rise building, Journal of Wind Engineering and Industrial Aerodynamics, 91, pp.807-828 (2003)

33) Ginger, J.D., Mehta, K. C. and Yeatts, B. B. : Internal pressures in a low-rise full-scale bulding, Journal of Wind Engineering and Industrial Aerodynamics, 72, pp.163-174 (1997)

34) Kandola, B.S. : Wind Effects on Buidings with Varying Leakage Characteristics - Wind -Tunnel Investigation, Journal of Industrial Aerodynamics, 3, pp.267-284 (1978)

35) Georgiou, P.N. and Vickery, B.J. : Wind Loads on Building Frames, Proceedings of the Fifth International Conference on Wind Engineering, Colorado State University, pp.421-433, July (1980)

36）上田宏、丸田栄蔵、本郷剛：網状構造物の抗力係数に関する研究，日本建築 学会構造系論文集, 第 524 号, 51-56, 1999.10

37) Richards, P.J. and Robinson, M:Wind loads on porous structures, Journal of Wind Engineering and Industrial Aerodynamics, 83, pp.455-465 (1999)

38) Holdø, A.E., Houghton, E.L. and Bhinder, F.S. : Effects of Permeability on Wind Loads on Pitched-roof Buildings, Journal of Wind Engineering and Industrial Aerodynamics, 12, pp.255-279 (1983)

39）日本建築学会荷重指針・同解説 $(2004)$

40) Tryggvason, B.V. : Aeroelastic Modelling of Pneumatic and Tensioned Fabric Sturctures, Proceedings of the Fifth International Conference on Wind Engineering, Colorado State University, pp. 1061-1072, July (1980) 